\title{
Stream's regime coefficient in upstream Rokan watershed of Riau Province
}

\author{
Yohanna Lilis Handayani ${ }^{1,}{ }^{\text {, }}$, Siswanto $^{1}$, Bambang Sujatmoko ${ }^{1}$, and Gumi Oktavia ${ }^{1}$ \\ ${ }^{1}$ Department of Civil Engineering, Universitas Riau, Pekanbaru, Indonesia
}

\begin{abstract}
Flood disaster in Rokan Hulu Regency often occurs every year. High streamflow conditions during rainy season as one of the causes of the flood. Stream's Regime Coefficient (KRS) is the ratio of maximum and minimum discharge in a watershed that shows the watershed condition. The higher KRS means the worse the watershed condition. The study areas are located in the upstream Rokan watershed. Upstream Rokan watershed with the AWLR (Automatic Water Level Recorder) Lubuk Bendahara and Pasir Pangaraian in Riau Province were picked up as study area of this research. The results show the indicator of stream's regime coefficient at Lubuk Bendahara AWLR valued 217.45 which placed on poor class and the indicator of stream's regime coefficient at Pasir Pangaraian AWLR valued 38.25 which placed on good class.
\end{abstract}

\section{Introduction}

Watershed is a land area which is a unit with the river and its tributaries. The river flow area functions to accommodate, store and drain water from rainfall to the lake or the sea naturally and are restricted to waters that are still affected by land activities [1]. Watershed management means the allocation of natural resources in watersheds including flood prevention, erosion, and resource-related protection. Included in watershed management is identifying the linkages between upstream and downstream areas of a watershed. Watershed conditions will be disrupted when coefficient of the river regime tends to increase gradually, and the groundwater level has an extreme fluctuation [2].

Erosion, flooding, drought, river siltation are the fact that the hydrological conditions of a watershed are deteriorating and the quality of natural resources is deteriorating in almost all watersheds in Indonesia. The upstream watershed ecosystem is a very important part because it has the function of protecting all parts of the watershed, one of which is a function of water management [3]. Damage to the upper watershed area as water catchment is suspected to be one of the main causes of natural disasters such as floods and erosion [4].

These conditions indicate that management in the watershed area currently is less effective and less efficient. This is reflected in the lack of control of the floods in the rainy season and drought in the dry season. Floods and droughts are caused by land use and water resources that are not yet in accordance with good watershed management. One indicator that good watershed management is the KRS value. KRS value (Stream's Regime

\footnotetext{
* Corresponding author: ylilish@eng.unri.ac.id
} 
Coefficient) is the ratio between the maximum discharge (Qmax) and the minimum discharge (Qmin) in a watershed. If the KRS value is $<50$, then the watershed is in excellent condition. This shows that the continuity of flow in the watershed is sufficiently maintained, where during the rainy season it can store water and during the dry season it can be released [5].

There are two subbasins at upstream Rokan, the Rokan Kiri Sub-watershed and the Rokan Kanan Sub-watershed. The Rokan Kiri Sub-watershed is in the Rokan IV Koto District. Rokan IV Koto District has an area of $\pm 871.16 \mathrm{~km}^{2}$, which has 14 villages. The government center is in the Rokan village which has a population of 24,125 people and an average population density of 28 people $/ \mathrm{km}^{2}$. The Rokan Kanan sub-watershed is in the Rambah sub-district. Rambah Sub-district has an area of $6396.61 \mathrm{~km}^{2}$ which has 14 Villages. The government center is in Pasir Pangaraian Village which has a population of 52,345 people with an average population density of 132 people $/ \mathrm{km}^{2}$ [6].

AWLR (Automatic Water Level Recorder) in the Rokan Kanan sub-watershed is named Pasir Pangaraian AWLR. This station is located on the Batang Lubuh River, Pasir Pangaraian village. AWLR in the left Rokan Sub-watershed is named Lubuk Bendahara AWLR. This station is located on the Rokan River, Lubuk Bendahara Village.

This study uses regulations in the Ministry of Forestry, which is based on the regulation of the Director General of Land Rehabilitation and Social Forestry number: P.04/ VSET/2009, concerning the monitoring and evaluation of watersheds. One part of the rule is the water management criteria with an indicator of river water discharge [7]. The purpose of this study was to determine the condition of the Rokan Kiri Sub-watershed and the Rokan Kanan Sub-watershed based on the KRS value. The benefit of this study is to provide information in determining policies based on the KRS value in the Rokan watershed.

\section{Literature review}

\subsection{Stream's regime coefficient}

Stream's Regime Coefficient (KRS) is the ratio between maximum discharge (Qmax) and minimum discharge (Qmin) in a basin/watershed [7-8]. Before calculating the KRS value, the AWLR (Automatic Water Level Recorder) data must be calculated by using the rating curve. Rating curve of Pasir Pangaraian AWLR with the formula used is [8]:

$$
Q=47,662 \times(H-0.140)^{1.950}
$$

where $Q$ and $H$ represent discharge $\left(\mathrm{m}^{3} / \mathrm{s}\right)$ and gage height (m)

Qmax and Qmin data are obtained from the average daily discharge (Q) from AWLR data. The stream's regime coefficient (KRS) can be calculated using the formula below [9]:

$$
K R S=\frac{Q_{\max }}{Q_{\min }}
$$

where $Q \max$ and $Q \min$ represent maximum daily discharge $\left(\mathrm{m}^{3} / \mathrm{s}\right)$ and minimum daily discharge $\left(\mathrm{m}^{3} / \mathrm{s}\right)$.

Classification of KRS values to show water management characteristics in the watershed as shown in Table 1 [7]. The high KRS shows that the runoff is high (flooding occurs) in the rainy season, while the runoff in the dry season is very small (drought). This situation indicates the land absorption in the watershed/ sub-watershed is relatively small. The land is less able to hold and store rainwater so the runoff was large that flown into the 
river and wasted in sea. This will reduce water availability in the watershed/sub-watershed during the dry season $[7,9]$.

Table 1. Classification of KRS value.

\begin{tabular}{|c|c|}
\hline KRS value & Classification \\
\hline$<50$ & Good \\
\hline $50-120$ & Medium \\
\hline$>120$ & Poor \\
\hline
\end{tabular}

River flow regime change is strongly influenced by the hydrological characteristics of the river basin. The main characteristics of a river basin are rainfall and land cover types. Rainfall in a river basin generates runoff, which eventually joins the river. During this movement, the factor of land cover type influences the amount of water that will finally join the river and become available for use. Land cover type is determined by land use type. Activities that change land use types can enhance or reduce the water yield [2].

Different flow regime patterns can be treated as some "preferred states" of the runoff system, which are more or less stable. Under the influence of changing climatic conditions, a flow regime might destabilize and turn over to another one with sometimes quite different seasonal patterns of high and low water, thus disturbing the established hydro-ecological conditions and water uses. The importance of such a change will depend on the sensitivity of a specific regime pattern to the changing climate [10].

\section{Methods}

\subsection{Study area}

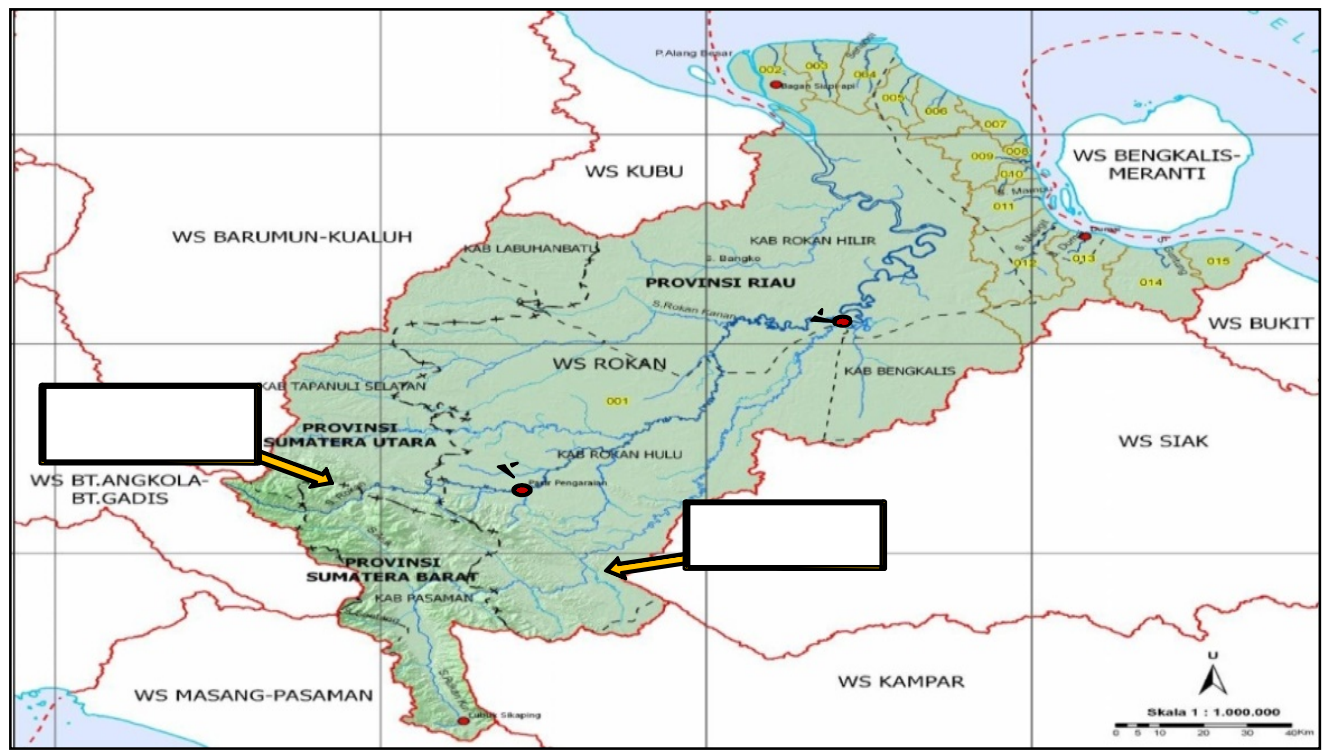

Fig. 1. Study area of research. 
This research was conducted on the Rokan Kiri Sub-watershed and Rokan Kanan Subwatershed. Discharge data from Lubuk Bendahara AWLR in the Rokan Kiri Sub-watershed and Pasir Pangaraian AWLR in the Rokan Kanan Sub-watershed. The research location is shown in Fig. 1 [6]. AWLR Lubuk Bendahara is administratively located in Lubuk Bendahara Village, Rokan IV Koto District, Rokan Hulu Regency in Riau. Geographically located at $00^{\circ} 41^{\prime} 29^{\prime \prime} \mathrm{LU}$ and $100^{\circ} 13^{\prime} 14^{\prime \prime} \mathrm{BT}$. This station has a watershed area of $3196 \mathrm{~km}^{2}$. AWLR Pasir Pangaraian is administratively located in Pasir Pangaraian Village, Rambah District, Rokan Hulu Regency, Riau Province. The station's geographical location is at $00^{\circ} 35^{\prime} 24^{\prime \prime} \mathrm{LS}$ and $101^{\circ} 11^{\prime} 46^{\prime \prime} \mathrm{BT}$. This station has a watershed area of $1036 \mathrm{~km}^{2}$.

\subsection{Research step}

The study was carried out as follows. First, a literature study to find several theories and references that support research. Second, collection of secondary data. Secondary data are characteristics of the watershed, daily rainfall data (2006-2015) and daily discharge data (2006-2015). Third, calculate and analyze the River Regime Coefficient (KRS) from the daily debit every year. Fourth, determine the classification of KRS values based on the regulation of the Director General of Land Rehabilitation and Social Forestry number: P.04/ V-SET/ 2009. Finally, analysis and discussion.

\section{Results and discussions}

\subsection{Analysis of Stream's Regime Coefficient}

\subsubsection{Stream's regime coefficient (KRS) at Lubuk Bendahara AWLR}

The results of the KRS analysis in the Lubuk Bendahara AWLR are shown in Table 2. The average value of KRS in the Lubuk Bendahara AWLR from 2006 to 2015 was 217.47. This value is in the poor category because the value is higher than 120 .

Table 2. Stream's regime coefficient (KRS) at Lubuk Bendahara AWLR.

\begin{tabular}{|c|c|c|c|c|}
\hline Year & $\mathbf{Q} \mathbf{m a x}\left(\mathbf{m}^{3} / \mathbf{s}\right)$ & $\mathbf{Q} \mathbf{m i n}\left(\mathbf{m}^{3} / \mathbf{s}\right)$ & $\mathbf{K R S}=\mathbf{Q} \mathbf{m a x} / \mathbf{Q} \mathbf{m i n}$ & Classification \\
\hline 2006 & 673.87 & 2.95 & 228.4 & Poor \\
\hline 2007 & 834.21 & 1.87 & 446.1 & Poor \\
\hline 2008 & 576.24 & 4.56 & 126.36 & Poor \\
\hline 2009 & 789.83 & 3.45 & 228.93 & Poor \\
\hline 2010 & 922.59 & 7.6 & 121.39 & Poor \\
\hline 2011 & 918.66 & 6.15 & 149.37 & Poor \\
\hline 2012 & 841.73 & 6.86 & 122.7 & Poor \\
\hline 2013 & 887.49 & 3.71 & 239.21 & Poor \\
\hline 2014 & 506.45 & 1.34 & 377.94 & Poor \\
\hline 2015 & 304.86 & 2.27 & 134.29 & Poor \\
\hline
\end{tabular}


It can be seen that the lowest KRS value was 121.39 in 2010 while the highest KRS value was 446.1 in 2007 . This means that runoff during the rainy season is relatively high, while the discharge during the dry season is relatively low. This shows that the Rokan Kiri Sub-watershed has a low infiltration ability, so most of the rainwater flows into the river. If this river capacity cannot accommodate runoff, then there will be a flood. Low infiltration affects the groundwater recharge so that during the dry season the minimum discharge is relatively small. Low infiltration capability is caused by impermeable land use conditions and does not support water conservation in the subbasin.

Discharge fluctuations are also affected by the amount of rain. During the rainy season, the maximum discharge will be high while during the dry season, the minimum discharge is low. In Fig. 2 and Fig. 3, there is a relatively significant difference between the amount of rain at maximum discharge and minimum discharge.

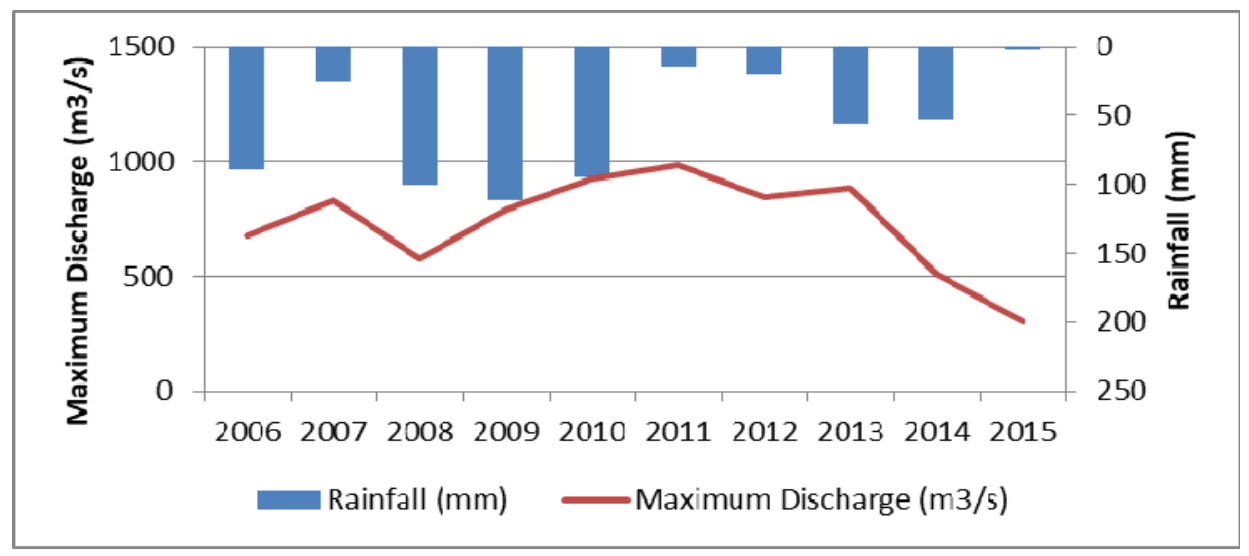

Fig. 2. Comparison of Qmax and rainfall at Lubuk Bendahara AWLR.

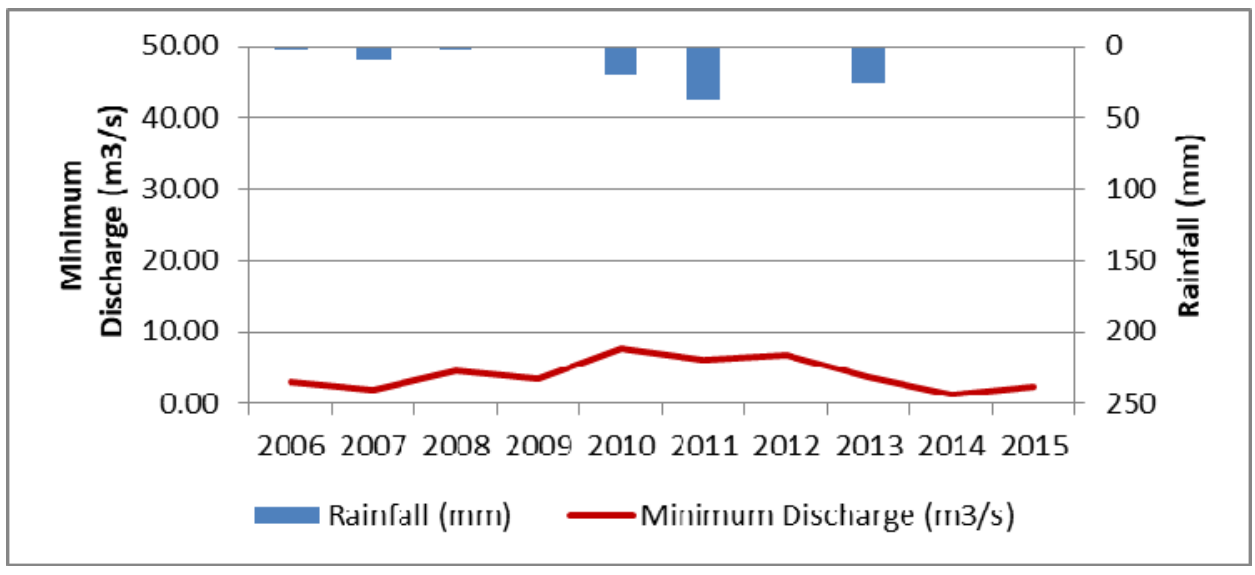

Fig. 3. Comparison of Qmin and rainfall at Lubuk Bendahara AWLR.

\subsubsection{Stream's regime coeffisien (KRS) at Pasir Pangaraian AWLR}

The KRS value in AWLR Pasir Pangaraian is shown in Table 3. The average value of stream regime coefficients from 2006 to 2015 is 38.25 and the classification is included in a good class because the value is lower than 50 . 
Table 3. River regime coefficient (KRS) at Pasir Pangaraian AWLR

\begin{tabular}{|c|c|c|c|c|}
\hline Year & Qmax (m $\left.{ }^{3} \mathbf{s}\right)$ & Qmin $\left(\mathbf{m}^{3} / \mathbf{s}\right)$ & KRS= Qmax/Qmin & Clasification \\
\hline 2006 & 585.671 & 13.316 & 43.982 & Good \\
\hline 2008 & 786.181 & 32.368 & 24.289 & Good \\
\hline 2009 & 684.038 & 10.485 & 65.242 & Medium \\
\hline 2010 & 245.965 & 2.066 & 119.040 & Medium \\
\hline 2011 & 491.855 & 13.820 & 35.590 & Good \\
\hline 2012 & 424.710 & 31.602 & 13.439 & Good \\
\hline 2013 & 573.118 & 27.910 & 20.535 & Good \\
\hline 2014 & 536.254 & 54.384 & 9.861 & Good \\
\hline 2015 & 333.014 & 27.198 & 12.244 & Good \\
\hline
\end{tabular}

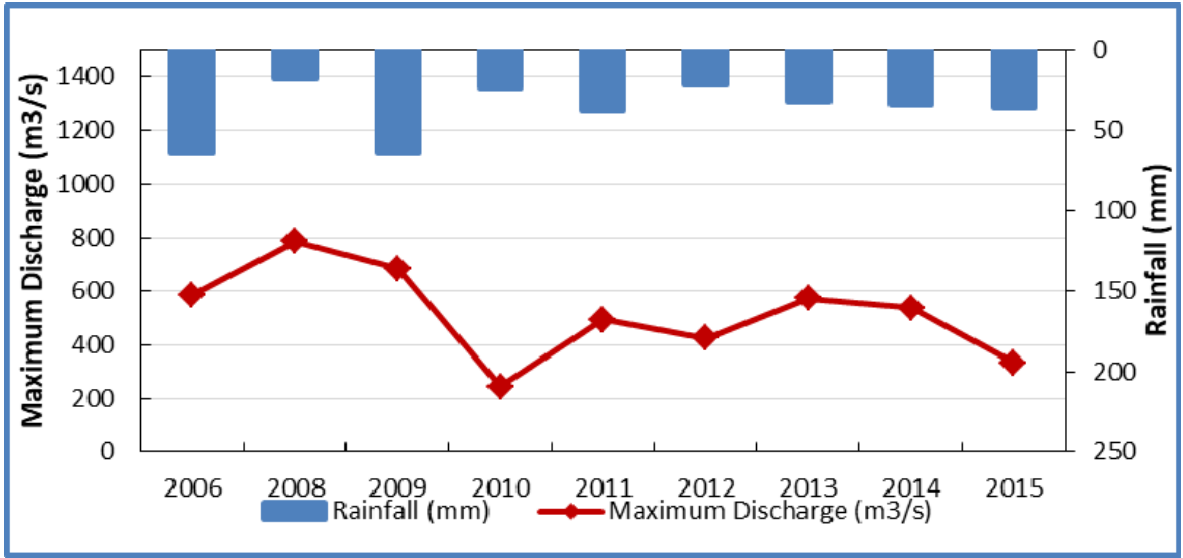

Fig. 4. Comparison of Qmax and rainfall at the Pasir Pangaraian AWLR.

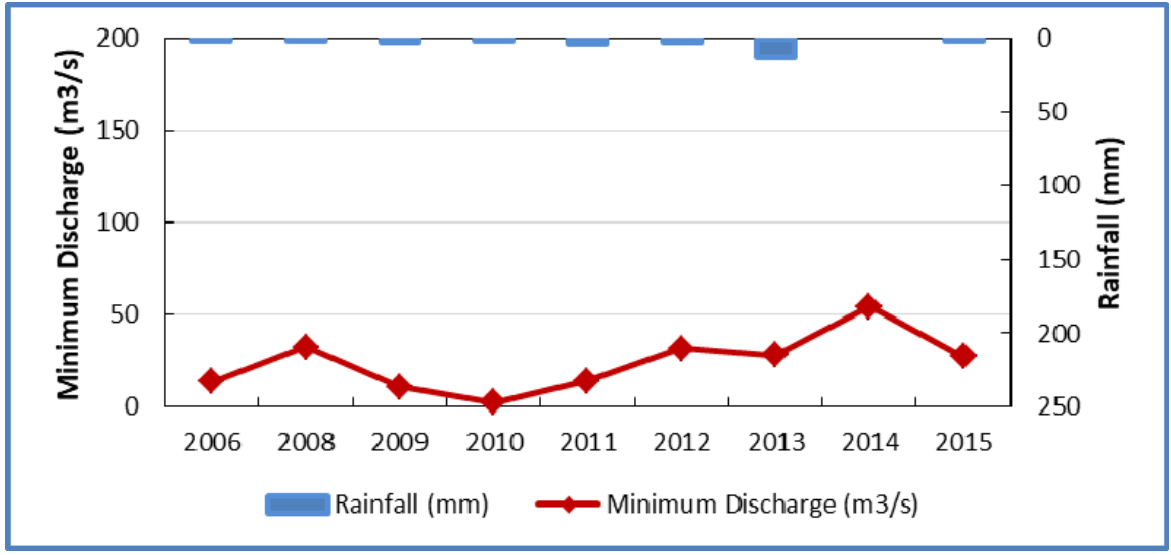

Fig. 5. Comparison of Qmin and rainfall at the Pasir Pangaraian AWLR. 
Based on the KRS value in Table 3, it can be seen that almost every year the KRS value in Pasir Pangaraian AWLR is in a good classification. This shows that the conditions of the Rokan Kanan sub-watershed are generally still good compared to the conditions of the Rokan Kiri sub-watershed. The highest KRS value in 2010, even though the Qmax and Qmin values are the lowest. It can be seen from Fig. 4 and 5 in 2010 that the depth of rain is not too high compared to other years. This could be influenced by other natural factors, namely the influence of El Nino which caused extreme weather in 2010 [11].

El Nino events will affect the amount of rainfall. The El Niño phenomenon can cause drought while La Nina causes flooding. In general, the amount of rainfall is below normal when in El Niño, but above normal when in La Niña. El Niño and La Niña events cause non-seasonal variations in Indonesian territory.[12]

\section{Conclusions}

The results of this study can be concluded that the value of the River Regime Coefficient (KRS) in the Rokan Kiri sub-watershed on average from 2006 to 2015 is 223.92 so that the value of the River Regime Coefficient (KRS) can be classified in bad conditions, while the value of the River Regime Coefficient (KRS) in the Rokan Kanan sub-watershed on average from 2002 to 2017 is 36.11 so that the value of the River Regime Coefficient (KRS) can be classified in good condition. Based on the KRS value, the condition of the Rokan Kanan sub-watershed is better than the condition of the Rokan Kiri sub-watershed.

The author would like to thank the Riau University for its research grants program.

\section{References}

1. Anonim, Peraturan Pemerintah Republik Indonesia Nomor 37 Tahun 2012 tentang Pengelolaan Daerah Aliran Sungai (2012)

2. C. Asdak, Hidrologi dan pengelolaan daerah aliran sungai (UGM, Yogyakarta, 2014)

3. W. Anggara, Studi penentuan kinerja pengelolaan DAS di sub DAS Konto Hulu. (Universitas Brawijaya, Malang, 2014)

4. Mahmud, Penilaian status daerah aliran sungai (Studi kasus sub DAS Serang) (Universitas Negeri Papua, Papua Barat, 2009)

5. S. Retnowati, Dampak alih fungsi lahan terhadap kondisi tata air di sub-sub ngunut I dan sub-sub DAS Tapan (Sub DAS Samin) (UNS, Surakarta, 2012)

6. Badan Pusat Statistik, Kabupaten Rokan Hulu Kecamatan Rokan IV Koto dalam angka 2016 (Badan Pusat Statistik, Pekanbaru, 2016)

7. Menteri Kehutanan, Surat Keputusan Menteri Kehutanan No P.04/V-SET/2009 Tentang Pedoman Monitoring dan Evaluasi Daerah Aliran Sungai (DAS) (2001)

8. M. Prayudi, Sensitivitasi parameter HEC-HMS untuk menentukan debit pada DAS Batang Lubuh Pasir Pangaraian (Universitas Riau, Pekanbaru 2016)

9. M. Khairullah, Kinerja Sub DAS Siak bagian hulu dalam pengelolaan DAS Siak. (Universitas Riau, Pekanbaru 2015)

10. I. Krasovskaia, L. Gottschalk, Hydrological Sciences J. 47, 4 (2002)

11. Liputan 6, BMKG: Cuaca 2010 terekstrim selama 12 tahun. https://www.liputan6.com/news/read/290868/bmkg-cuaca-2010-terekstrem.html

12. B. Tjasyono, A. Lubis, I. Juaeni, Ruminta, S. Woro, B. Harijono, J. Sains Dirgantara, 5, 2 (2008) 